\title{
FORMULASI FLAKES PATI GARUT DAN TEPUNG IKAN LELE DUMBO (Clarias gariepinus) SEBAGAI PANGAN KAYA ENERGI PROTEIN DAN MINERAL UNTUK LANSIA
}

\author{
(Flakes Formulation of Arrowroot Starch and Dumbo Catfish Flour [Clarias gariepinus] \\ as a Rich Food in Protein Energy and Mineral for Elderly)
}

Firda Amalia ${ }^{*}$ dan Clara M Kusharto ${ }^{1}$

'Departemen Gizi Masyarakat, Fakultas Ekologi Manusia (FEMA), Institut Pertanian Bogor, Bogor 16680

\begin{abstract}
The objective of this study was to produce arrowroot starch flakes with dumbo catfish (Clarias gariepinus) flour, as a rich energy, protein, and mineral food for elderly. Design of this study was complete randomized design with four formulas and each combination was replicated two times. A selected formula was determined based on semi trained panelists preference. Acceptance of selected flakes formula was examined by elderly using hedonic test. Flakes by addition of $33.00 \%$ of dumbo catfish flour was the selected formula. The chemical properties for selected flakes were as follows $4.00 \%$ of water, $4.84 \%$ ash, $16.90 \%$ protein, $5.21 \%$ fat, $69.06 \%$ carbohydrate, $14.48 \%$ calcium, and $8.61 \%$ phosphor. The selected flakes contain $391 \mathrm{kcals}$ energy per $100 \mathrm{~g}$. The selected flakes had contributed more than $20.00 \%$ of energy, protein, calcium, and phosphor for elderly people so it can be claimed as a food product rich in energy, protein and minerals.
\end{abstract}

Keywords: arrowroot starch, dumbo catfish flour, flakes, mineral, protein

\begin{abstract}
ABSTRAK
Tujuan penelitian ini adalah untuk menghasilkan flakes pati garut dan tepung ikan lele dumbo (Clarias gariepinus) sebagai pangan kaya energi, protein, dan mineral untuk lansia. Desain penelitian menggunakan Rancangan Acak Lengkap dengan empat formula dan setiap kombinasi diulang dua kali. Formula terpilih ditentukan berdasarkan preferensi panelis agak terlatih. Penerimaan flakes terpilih oleh lansia dilakukan dengan menggunakan uji hedonik. Flakes dengan penambahan tepung ikan lele dumbo sebanyak $33.00 \%$ merupakan formula terpilih. Sifat kimia flakes terpilih yaitu $4.00 \%$ kadar air, $4.84 \%$ abu, $16.90 \%$ protein, $5.21 \%$ lemak, $69.06 \%$ karbohidrat, $14.48 \%$ kalsium, dan $8.61 \%$ fosfor. Flakes terpilih mengandung 391 kkal energi per 100 g. Flakes terpilih memiliki kontribusi lebih dari $20.00 \%$ untuk energi, protein, mineral kalsium, dan fosfor untuk lansia sehingga dapat diklaim sebagai produk makanan yang kaya energi, protein, dan mineral.
\end{abstract}

Kata kunci: flakes, mineral, pati garut, protein, tepung ikan lele dumbo

"Korespondensi: Departemen Gizi Masyarakat, Fakultas Ekologi Manusia (FEMA), Institut Pertanian Bogor, Bogor 16680. Email: firdaamalia25@ymail.com 


\section{PENDAHULUAN}

Ketergantungan masyarakat Indonesia pada bahan pangan tertentu dapat melemahkan ketahanan pangan nasional dilihat dari tingkat impor gandum dan tepung terigu yang masih tinggi. Indonesia memiliki beberapa komoditi lokal yang berpotensi sebagai makanan pokok pengganti gandum dan tepung terigu. Umbi garut (Maranta arundinaceae) merupakan salah satu sumber daya pangan lokal di Indonesia yang tersedia cukup melimpah. Ketersediaan umbi garut di Indonesia cukup banyak terlihat pada kapasitas produksi rata-rata sebesar 8 ton/hektar atau 3080 ton sekali panen. Salah satu olahan utama umbi garut adalah pati garut sebagai salah satu bentuk karbohidrat alami yang murni dan memiliki kekentalan yang tinggi, pati garut memiliki kandungan lemak yang rendah serta kandungan fosfor dan zat besi yang lebih tinggi dibandingkan tepung terigu (Jyothi et al. 2009). Akan tetapi ketersediaannya yang cukup banyak serta keunggulan yang dimiliki tidak diikuti dengan pemanfaatannya yang masih tergolong rendah.

Lanjut usia atau lansia menurut Undang-Undang RI Nomor 13 Tahun 1998 tentang Kesejahteraan Lanjut Usia adalah seseorang yang telah mencapai usia 60 tahun ke atas. Pada kelompok lansia, zat gizi yang bermutu baik tetap diperlukan dalam pembentukan jaringan tubuh untuk pergantian jaringanjaringan yang rusak (Manton et al. 2007). Konsumsi makanan yang cukup dan seimbang dapat bermanfaat bagi lansia untuk mencegah atau mengurangi kemungkinan penyakit degeneratif dan kekurangan gizi (Rusilanti \& Kusharto 2006). Oleh karena itu, diperlukan pangan yang mengandung zat gizi yang cukup dan sesuai dengan kebutuhan lansia baik jumlah maupun komposisinya. Namun pengembangan produk yang memerhatikan kebutuhan zat gizi untuk lansia masih tergolong sedikit dan sulit ditemukan.

Berdasarkan fakta tersebut maka dibutuhkan suatu bentuk makanan untuk lansia yang mudah serta cepat disajikan yaitu flakes. Akan tetapi produk flakes yang beredar di masyarakat luas masih menggunakan bahan dasar gandum. Pengembangan produk flakes yang kaya energi dan zat gizi dengan bahan dasar pati garut penting dilakukan sebagai usaha untuk mengurangi impor gandum dan meningkatkan diversifikasi pangan masyarakat Indonesia. Pembuatan flakes pati garut dapat meningkatkan nilai tambah umbi garut dan sangat tepat untuk lansia karena kandungan energi yang tinggi dan rendahnya indeks glikemik pada pati garut se-hingga asupan energi dapat terpenuhi tanpa adanya kenaikan gula darah yang terlalu cepat. Akan tetapi, hal ini masih dirasa kurang karena umbi garut memiliki kandungan protein yang rendah (Jyothi et al. 2009).
Oleh karenanya, penting dilakukan peningkatan kandungan protein dan mineral dengan menggunakan tepung ikan lele dumbo (Clarias gariepinus). Penambahan tepung ikan lele dumbo sebagai bahan pangan hewani memiliki beberapa keunggulan dibandingkan sumber protein lainnya karena kandungan protein yang cukup tinggi yang tersusun oleh pola asam-asam amino yang mendekati kebutuhan asam amino manusia. Selain itu, tepung ikan lele dumbo mengandung sejumlah mineral dan vitamin yang diperlukan tubuh (Li et al. 2007). Penambahan tepung ikan lele dumbo diharapkan dapat meningkatkan nilai protein dan mineral pada flakes berbasis bahan pangan lokal yaitu pati garut.

Tujuan khusus dari penelitian ini adalah 1) mendapatkan formula flakes pati garut dengan penambahan tepung ikan lele dumbo sebagai sumber protein hewani dan mineral untuk pemenuhan kebutuhan lansia; 2) menganalisis sifat organoleptik flakes; 3) menganalisis pengaruh penambahan tepung ikan lele terhadap sifat fisik dan kimia produk flakes; 4) menghitung kontribusi zat gizi yang dapat diberikan flakes tehadap Angka Kecukupan Gizi (AKG) lansia.

\section{METODE}

\section{Desain, Tempat, dan Waktu}

Desain yang digunakan dalam penelitian ini adalah rancangan acak lengkap dengan dua kali ulangan yang terdiri dari satu faktor yaitu proporsi penambahan tepung ikan lele dumbo terhadap adonan flakes pati garut yang terdiri atas empat taraf F0 (0.00\%), F1 (28.00\%), F2 (33.00\%), dan F3 $(38.00 \%)$ dari total kombinasi tepung yang digunakan dalam pembuatan flakes selain tepung kepala dan badan ikan lele dumbo yaitu pati garut, tepung kedelai, dan tapioka. Penelitian dilaksanakan pada bulan Nopember 2012-April 2013. Formulasi produk flakes dilakukan di Laboratorium SEAFAST, IPB. Uji organoleptik dilakukan pada panelis agak terlatih untuk menentukan produk flakes terpilih dan pada panelis lansia untuk melihat tingkat penerimaan dari produk flakes yang dilakukan di Laboratorium Organoleptik, Departemen Gizi Masyarakat, FEMA, IPB dan di Poslansia Jl. Setu Tengah RT 02/03 Kelurahan Sinarsari Kecamatan Dramaga Kabupaten Bogor. Analisis fisik dan analisis kimia produk flakes dilakukan di Laboratorium Pusat Antar Universitas (PAU) dan Laboratorium Analisis Zat Gizi, Departemen Gizi Masyarakat, FEMA, IPB.

\section{Bahan dan Alat}

Bahan yang digunakan adalah pati garut, tepung ikan lele dumbo, tepung kedelai, tepung tapioka, gula, garam, dan air. Bahan kimia yang 
digunakan untuk analisis kandungan gizi adalah aquades, $\mathrm{H}_{2} \mathrm{SO}_{4}$ pekat, selenium mix, $\mathrm{NaOH}$, pelarut Hexana, $\mathrm{HNO}_{3}, \mathrm{HCl}$, ammonium molibdat, potassium dihidrogen, etanol $95 \%$, metil merah.

Alat-alat yang digunakan dalam pembuatan tepung kedelai antara lain oven pemanggang, pin disc mill, dan ayakan 60 mesh. Alat yang digunakan untuk membuat flakes antara lain mixer, grinder, roller, loyang, dan oven pemanggang. Alat-alat yang digunakan dalam analisis fisik adalah Texture Analyzer, vortex, dan centrifuge. Alat-alat yang digunakan dalam analisis kimia adalah oven, tanur, desikator, kondensor, soxhlet, labu Kjedahl, alat destilasi, labu Erlenmayer, AAS (Atomic Absorption Spectrophotometer).

\section{Tahapan Penelitian}

Formulasi flakes menggunakan empat taraf penambahan tepung ikan lele dengan perbandingan tepung kepala dan badan ikan lele sebesar 3:7 disajikan pada Tabel 1.

Selanjutnya dilakukan uji organoleptik yang meliputi uji pada panelis agak terlatih dan uji pada panelis lansia. Uji organoleptik pada panelis agak terlatih dilakukan menggunakan tujuh skala terhadap empat parameter yaitu warna, aroma, rasa, dan tekstur. Berdasarkan hasil uji organoleptik pada panelis agak terlatih ditentukan formula terpilih yang akan diuji organoleptik pada lansia, kemudian dianalisis sifat fisik dan kimianya serta dilakukan penilaian kontribusi zat gizi produk flakes terhadap kebutuhan zat gizi dengan menggunakan AKG lansia.

\section{Pengolahan dan Analisis Data}

Data hasil uji organoleptik pada panelis agak terlatih untuk menentukan formula terpilih dianalisis secara deskriptif menggunakan nilai rata-rata dan persentase penerimaan panelis terhadap formula flakes. Untuk mengetahui pengaruh perlakuan dan tingkat kesukaan panelis terhadap flakes digunakan uji Friedman. Apabila hasil ini menunjukkan adanya perbedaan diantara perlakuan maka dilakukan uji lanjut Duncan. Penerimaan flakes pada panelis lansia dianalisis secara deskriptif menggunakan nilai rata-rata, persentase penerimaan, dan persentase flakes yang dikonsumsi. Untuk mengetahui pengaruh penambahan tepung ikan lele dumbo terhadap sifat fisik dan kimia flakes kontrol dan terpilih dianalisis menggunakan uji beda independent samples.

\section{HASIL DAN PEMBAHASAN}

\section{Formulasi Flakes}

Formula flakes yang digunakan mengacu pada formula flakes hasil Iriawan (2012) dalam pembuatan flakes ubi jalar dengan penambahan tepung ikan lele dengan beberapa modifikasi sehingga flakes memiliki tekstur yang baik dan kompak. Selain berdasarkan pada karakteristik fisik flakes, formula juga didasarkan pada kebutuhan energi dan protein pada lansia. Selain itu flakes diharapkan dapat memenuhi syarat kriteria flakes menurut Standar Nasional Indonesia (SNI) dan dapat diterima oleh lansia. Menurut Badan Pengawas Obat dan Makanan (BPOM) produk makanan diklaim kaya akan kandungan gizi apabila memenuhi sedikitnya 20\% jika produk dalam bentuk padat dan $15 \%$ jika produk dalam bentuk cair dari Acuan Label Gizi (ALG) yang dianjurkan per saji. Oleh karena itu, untuk memenuhi kriteria tersebut, flakes yang dihasilkan minimal mengandung $12 \mathrm{~g}$ protein, $160 \mathrm{mg}$ kalsium, dan $120 \mathrm{mg}$ fosfor per sajian.

Faktor perlakuan yang digunakan pada rancangan formula adalah perbedaan penambahan tepung ikan lele dumbo. Banyaknya tepung ikan lele dumbo yang ditambahkan adalah $0.00 \%$ (F0), $28.00 \%$ (F1), $33.00 \%$ (F2), dan $38.00 \%$ (F3) dari total kombinasi tepung yang digunakan dalam pembuatan flakes selain tepung kepala dan badan ikan lele

Tabel 1. Formulasi Flakes Pati Garut dengan Tepung Ikan Lele

\begin{tabular}{lcccc}
\hline \multirow{2}{*}{ Bahan Pangan (g) } & \multicolumn{4}{c}{ Berat Bahan (g) } \\
\cline { 2 - 5 } & F0 (0.00\%) & F1 (28.00\%) & F2 (33.00\%) & F3 (38.00\%) \\
\hline Pati Garut & 140.00 & 140.00 & 140.00 & 140.00 \\
Tepung Kepala Ikan Lele & 0.00 & 18.00 & 21.00 & 24.00 \\
Tepung Badan Ikan Lele & 0.00 & 42.00 & 49.00 & 56.00 \\
Tepung Tapioka & 40.00 & 40.00 & 40.00 & 40.00 \\
Tepung Kedelai & 30.00 & 30.00 & 30.00 & 30.00 \\
Garam & 0.10 & 0.10 & 0.10 & 0.10 \\
Gula & 26.00 & 26.00 & 26.00 & 26.00 \\
Air & 100.00 & 100.00 & 100.00 & 100.00 \\
Total & 336.00 & 396.00 & 406.00 & 416.00 \\
\hline
\end{tabular}


dumbo yaitu pati garut, tepung kedelai, dan tapioka. Tepung ikan lele dumbo yang digunakan terdiri atas tepung kepala dan badan. Persentase penggunaan tepung kepala dan badan ikan lele mengacu pada Mervina et al. (2012) yaitu 3:7.

\section{Sifat Organoleptik Flakes Pati Garut \\ Hasil uji pada panelis agak terlatih. Pengu-}

jian sifat organoleptik bertujuan untuk menentukan formula flakes terpilih yang akan digunakan untuk penelitian selanjutnya. Berdasarkan hasil uji organoleptik mutu hedonik menunjukkan atribut warna, aroma, tekstur, dan rasa menunjukkan perbedaan yang nyata antar perlakuan $(p<0.05)$. Warna dinilai berkisar antara coklat muda sampai krem, aroma berkisar pada aroma sedang, tekstur berkisar antara sedang sampai renyah, dan rasa berkisar antara biasa sampai agak gurih.

Uji hedonik flakes menunjukkan bahwa terdapat perbedaan yang nyata pada atribut warna, tekstur, aroma, dan rasa flakes $(\mathrm{p}<0.05)$. Warna dinilai biasa sampai agak suka, aroma dinilai biasa sampai agak suka, tekstur dinilai biasa sampai agak suka, dan rasa dinilai biasa sampai agak suka. Atribut keseluruhan pada uji hedonik ditentukan berdasarkan hasil penjumlahan dari atribut warna, aroma, tekstur, dan rasa yang dikalikan dengan nilai bobot tertentu. Penentuan bobot didasarkan pada atribut yang paling memengaruhi penilaian. Bobot yang digunakan untuk atribut tekstur, aroma, rasa, dan warna flakes berturut-turut adalah $0.40,0.30,0.20$, dan 0.10.

Berdasarkan hasil uji kesukaan terhadap keseluruhan, flakes berada pada tingkat kesukaan biasa hingga agak suka. Persentase kesukaan secara keseluruhan yang tertinggi adalah pada formula F2, selain itu formula F2 juga memiliki penerimaan tertinggi pada atribut lain yaitu tekstur, rasa, dan aroma. Oleh karena itu, formula F2 (flakes dengan penambahan tepung ikan lele dumbo sebanyak 33\%) dipilih sebagai formula terpilih dengan mempertimbangkan penerimaan panelis. Formula terpilih tersebut kemudian dianalisis lebih lanjut pada tahap penelitian selanjutnya.

Hasil uji pada panelis lansia. Formula terpilih yang diperoleh dari hasil uji pada panelis agak terlatih kemudian diuji kembali penerimannya pada 40 panelis lansia dengan kriteria umur $\geq 60$ tahun. Panelis adalah anggota Poslansia Jl. Setu Tengah RT 02/03 Kelurahan Sinarsari Kecamatan Dramaga Kabupaten Bogor. Menurut Adriano et al. (2010), suatu produk makanan dikatakan dapat diterima konsumen apabila jumlah persentase konsumen yang menolak produk makanan kurang dari $50.00 \%$ dan mampu mengonsumsi makanan tersebut. Penilaian ini dilakukan dengan memberikan satu porsi flakes pati garut ( $35.00 \mathrm{~g}$ ) yang disajikan dengan susu cair, kemudian dilakukan atribut secara keseluruhan dan nilai dikategorikan menjadi lima yaitu suka, agak suka, biasa, agak tidak suka, dan tidak suka.

Berdasarkan hasil perhitungan yang ditampilkan pada Tabel 2 terlihat bahwa sebanyak 88.71\% panelis menyukai flakes pati garut dan tepung ikan lele dumbo. Nilai tersebut menunjukkan bahwa sebagian besar panelis menyukai produk ini dilihat dari tingkat penerimaan panelis sebesar $100.00 \%$. Oleh karena itu, berdasarkan tingkat penerimaan dan persen flakes yang dikonsumsi oleh lansia maka produk flakes ini dapat diterima oleh lansia.

\section{Sifat Fisik Flakes Pati Garut Terpilih}

Karakteristik fisik yang dianalisis adalah tingkat kekerasan dan daya serap air formula terpilih flakes F2 dibandingkan dengan formula kontrol F0 yaitu flakes pati garut tanpa penambahan tepung ikan lele.

Tingkat kekerasan. Analisis tingkat kekerasan dilakukan dengan menggunakan alat Texture Analyzer dengan dua kali pengulangan. Tingkat kekerasan flakes F2 adalah 190.45 gf dan flakes kontrol adalah 672.75 gf. Hasil analisis tingkat kekerasan terhadap kedua jenis flakes menunjukkan bahwa flakes kontrol cenderung memiliki tingkat kekerasan yang lebih tinggi dibandingkan dengan flakes F2. Flakes kontrol

Tabel 2. Hasil Uji Penerimaan Flakes Pati Garut pada Lansia

\begin{tabular}{lcccc}
\hline \multirow{2}{*}{ Daya Terima } & \multicolumn{4}{c}{ Flakes Pati Garut dengan Penambahan Tepung Ikan Lele Dumbo } \\
\cline { 2 - 5 } & Skor & $\mathrm{n}$ & Hasil & $\%$ \\
\hline Suka & 5 & 33 & 165 & 88.71 \\
Agak suka & 4 & 0 & 0 & 0.00 \\
Biasa & 3 & 7 & 21 & 11.29 \\
Agak tidak suka & 2 & 0 & 0 & 0.00 \\
Tidak suka & 1 & 0 & 0 & 0.00 \\
Jumlah & & 40 & 186 & 100.00 \\
Rata-rata & & 4.65 & & \\
\hline
\end{tabular}


memiliki tekstur yang kurang renyah dibandingkan flakes F2. Hal ini diduga kombinasi antara tepung ikan lele dan tepung kedelai dengan kadar protein yang tinggi cenderung membentuk tekstur yang lebih renyah dibandingkan jika hanya menggunakan pati garut.

Tekstur pangan ditentukan oleh kadar air, kadar lemak, dan kandungan karbohidrat struktural seperti selulosa, pati, dan bahan pektin, serta protein yang terkandung dalam suatu produk (Chen \& Stokes 2012). Protein dapat meningkatkan kemampuan gelasi sehingga dapat membentuk fleksibilitas atau kemampuan protein untuk terdenaturasi dan membentuk jaringan dengan ikatan silang (Chaunier et al. 2005). Hal ini dapat menjelaskan tekstur flakes yang semakin renyah ketika ditambahkan tepung ikan lele dengan kandungan protein yang tinggi. Hasil uji beda menunjukkan bahwa tingkat kekerasan flakes kontrol lebih besar secara nyata dibandingkan flakes F2 $(p<0.05)$. Dapat dikatakan bahwa penambahan tepung ikan lele dapat meningkatkan kerenyahan flakes.

Daya serap air. Daya serap air flakes F2 adalah $5.59 \mathrm{ml}$ dan daya serap air flakes kontrol adalah $2.29 \mathrm{ml}$. Hasil analisis uji daya serap air pada kedua produk flakes menunjukkan bahwa flakes kontrol memiliki daya serap air lebih kecil dibandingkan dengan flakes F2. Peningkatan daya serap air disebabkan oleh tingkat porositas dari bahan penyusun flakes terpilih lebih besar dibandingkan dengan flakes kontrol. Semakin tinggi porositas bahan maka semakin banyak jumlah air yang diserap bahan (Oey et al. 2008). Hasil uji beda menunjukkan bahwa daya serap air flakes kontrol lebih rendah secara nyata flakes F2 $(\mathrm{p}<0.05)$. Dapat dikatakan bahwa penambahan tepung ikan lele dapat meningkatkan daya serap air flakes.

\section{Kandungan Gizi Flakes}

Kandungan gizi produk flakes kontrol dan flakes F2 dianalisis menggunakan analisis proksimat untuk kadar air, kadar abu, kadar protein, kadar lemak, dan kadar karbohidrat dengan menggunakan metode by difference. Selain itu juga dilakukan analisis kalsium, fosfor, dan daya cerna protein serta perhitungan energi yang terkandung dalam produk flakes. Hasil analisis kandungan gizi produk flakes dapat dilihat pada Tabel 3.

Kadar air. Kadar air flakes F2 yaitu $4.00 \%$ (\%bb) lebih rendah dibandingkan dengan kadar air flakes kontrol yaitu $4.06 \%$ (\%bb). Hasil uji beda menunjukkan bahwa kadar air flakes F2 tidak berbeda nyata dengan flakes kontrol $(p>0.05)$. Syarat mutu flakes berdasarkan SNI 01-4270-1996 untuk susu sereal adalah kadar air maksimum 3.00\% (\%bb). Kadar air flakes kontrol dan flakes F2 yang dihasilkan berada di atas persyaratan SNI.

Kadar abu. Kadar abu flakes F2 yang dihasilkan yaitu 4.84\% (\%bk) lebih tinggi dibandingkan dengan kadar abu flakes kontrol yaitu 0.97\% (\%bk). Hasil uji beda menunjukkan bahwa kadar abu flakes kontrol berbeda nyata $(p<0.05)$ dengan kadar abu flakes F2. Hasil penelitian ini sejalan dengan penelitian Mervina et al. (2012) yaitu substitusi tepung ikan akan meningkatkan kandungan abu pada biskuit yang dihasilkan.

Berdasarkan syarat mutu flakes menurut SNI 01-4270-1996, kadar abu maksimum pada produk flakes adalah $4.00 \%$ (\%bk). Kadar abu formula kontrol berada di bawah batas maksimum syarat SNI sehingga telah memenuhi syarat mutu SNI. Namun pada flakes F2 memiliki kadar abu di atas batas maksimum syarat SNI untuk susu sereal. Hal ini diduga karena pengaruh penambahan tepung ikan lele dumbo yang meningkatkan kandungan mineral flakes F2 sehingga meningkat pula kadar abunya.

Kadar protein. Protein yang terdapat di produk flakes pati garut berasal dari protein tepung kepala, badan ikan lele dumbo, dan protein tepung kedelai. Kadar protein flakes F2 yaitu 16.90\% (\%bk) lebih tinggi dibandingkan dengan kadar protein flakes kontrol yaitu 5.54\% (\%bk). Hasil uji beda

Tabel 3. Hasil Analisis Kandungan Gizi Produk Flakes Pati Garut

\begin{tabular}{lcccc}
\hline \multicolumn{1}{c}{ Komponen } & Satuan & Flakes Kontrol & Flakes F2 & SNI $^{*}$ \\
\hline Air & $(\% \mathrm{bb})$ & 4.06 & 4.00 & Maks 3.00\% \\
Abu & $(\% \mathrm{bk})$ & 0.97 & 4.84 & Maks $4.00 \%$ \\
Protein & $(\% \mathrm{bk})$ & 5.54 & 16.90 & Min $5.00 \%$ \\
Lemak & $(\% \mathrm{bk})$ & 5.58 & 5.21 & Min $7.00 \%$ \\
Karbohidrat & $(\% \mathrm{bk})$ & 83.86 & 69.06 & Min $60.00 \%$ \\
Energi & $\mathrm{kkal}$ & 408 & 391 & \\
Kalsium & $\mathrm{mg}$ & 45.75 & 1448.50 & \\
Fosfor & $\mathrm{mg}$ & 100.70 & 861.50 & \\
Daya Cerna Protein & $\%$ & 63.13 & 74.85 & \\
\hline
\end{tabular}


menunjukkan bahwa kadar protein flakes kontrol berbeda nyata $(\mathrm{p}<0.05)$ dengan kadar protein flakes F2.

Kandungan protein pada flakes F2 adalah sebesar $16.90 \%$ (\%bk) atau setara dengan 16.90 g protein per $100.00 \mathrm{~g}$ produk. Dalam mencapai produk flakes kaya protein tersebut untuk kategori lansia dapat mengonsumsi produk flakes pati garut sebanyak $72.00 \mathrm{~g}$. Menurut estimasi sebelumnya menunjukkan kandungan protein pada produk flakes pati garut terpilih adalah sebesar $24.48 \%$ (\%bk) atau setara $24.48 \mathrm{~g}$ per $100 \mathrm{~g}$ produk. Namun hasil analisis produk menunjukkan hasil yang lebih rendah. Hal ini diduga dapat disebabkan oleh proses pengolahan produk yang melalui beberapa tahap hingga terjadi kerusakan protein. Menurut Sayed et al. (2003) reaksi yang terjadi dalam proses pemasakan flakes yang berperan dalam menentukan kandungan protein pada produk flakes ini antara lain reaksi Maillard dan degradasi Stecker. Reaksi Maillard yang disebabkan oleh proses pemanasan sebagai akibat reaksi antara gula pereduksi dengan asam amino lisis sehingga akan menghilangkan kandungan lisin dalam bahan pangan. Terjadi pula degradasi Strecker yang merupakan degradasi asam amino pada protein sehingga membentuk warna dan flavor tertentu.

Kadar lemak. Kadar lemak flakes F2 yaitu 5.21\% (\%bk) lebih rendah dibandingkan dengan kadar lemak flakes kontrol yaitu 5.58\% (\%bk). Hasil uji beda menunjukkan bahwa kadar lemak flakes F2 tidak berbeda nyata ( $p>0.05)$ dengan kadar lemak flakes kontrol. Kadar lemak yang terkandung dalam produk flakes berasal dari tepung kepala, badan ikan lele dumbo, dan tepung kedelai. Penambahan tepung ikan lele dumbo menurunkan kadar lemak flakes. Penambahan tepung ikan lele dumbo menyebabkan ikatan antar molekul pada adonan kurang kuat sehingga terdapat banyak rongga pada adonan. Hal ini menyebabkan adonan semakin poros sehingga laju penguapan semakin meningkat pada saat pengovenan. Oleh karenanya, lemak pada adonan mudah keluar dari adonan pada saat pengovenan. Kadar lemak flakes kontrol dan flakes F2 yang dihasilkan berada di bawah persyaratan SNI 01-4270-1996 untuk susu sereal, sehingga dapat dikatakan bahwa kadar lemak flakes kontrol dan flakes F2 telah memenuhi persyaratan mutu flakes berdasarkan SNI.

Kadar karbohidrat. Bahan yang menjadi sumber karbohidrat dalam pembuatan flakes adalah pati garut dan tepung tapioka. Kadar karbohidrat pada flakes dihitung dengan penentuan kadar karbohidrat kasar menggunakan metode by difference. Kadar karbohidrat flakes F2 yaitu 69.06\% (\%bk) lebih rendah dibandingkan dengan kadar karbohidrat flakes kontrol yaitu 83.86\% (\%bk). Hasil uji beda menunjukkan bahwa kadar karbohidrat flakes kontrol berbeda nyata $(p<0.05)$ dengan kadar karbohidrat flakes. Flakes F2 dan flakes kontrol telah memenuhi syarat kadar kabohidrat flakes sesuai SNI yaitu minimal $60.00 \%$ (\%bk).

Kadar kalsium. Penambahan tepung ikan lele dumbo bertujuan untuk meningkatkan kandungan kalsium pada produk flakes. Kadar kalsium pada flakes F2 yaitu 1448.50\% (\%bb) lebih tinggi dibandingkan dengan kadar kalsium produk flakes pati garut kontrol yaitu $45.75 \%$ (\%bb). Hasil uji beda menunjukkan bahwa kadar kalsium flakes F2 berbeda nyata dengan kadar kalsium pada flakes kontrol $(p<0.05)$.

Kadar fosfor. Penambahan tepung ikan lele dumbo bertujuan untuk meningkatkan kandungan fosfor pada flakes. Kadar fosfor flakes F2 yaitu $163.22 \%$ (\%bb) lebih tinggi dibandingkan dengan kadar fosfor flakes kontrol yaitu 45.82\% (\%bb). Hasil uji beda menunjukkan bahwa kadar fosfor flakes F2 berbeda nyata terhadap kadar fosfor flakes kontrol $(p<0.05)$. Hasil analisis menunjukkan perbandingan antara kalsium dan fosfor sebesar 1.7:1. Hal ini mengindikasikan bahwa kadar fosfor yang terdapat dalam flakes diduga tidak menghambat penyerapan kalsium.

Kandungan energi. Berdasarkan hasil perhitungan, rata-rata nilai energi flakes kontrol adalah sebesar 459 kkal per 100 g. Sedangkan rata-rata nilai energi flakes F2 adalah sebesar 444 kkal per $100 \mathrm{~g}$. Berdasarkan hasil uji beda menunjukkan bahwa kandungan energi flakes kontrol berbeda nyata dengan kandungan pada produk flakes $\mathrm{F} 2(\mathrm{p}<0.05)$. Kandungan karbohidrat menurun seiring dengan penambahan tepung ikan lele dumbo. Hal ini menyebabkan energi flakes pati garut pun menurun seiring dengan penambahan tepung ikan lele dumbo pada flakes pati garut.

Daya cerna protein. Penambahan tepung ikan lele dumbo dilakukan dalam upaya melengkapi kandungan protein pada produk flakes. Dibandingkan flakes kontrol, flakes F2 memiliki daya cerna yang lebih tinggi yaitu sebesar $75.00 \%$. Daya cerna protein formula kontrol yaitu sebesar $58.00 \%$. Hal ini menunjukkan bahwa flakes F2 memiliki daya cerna protein yang lebih baik dibandingkan formula kontrol. Menurut hasil uji beda antara kontrol dan flakes F2 menunjukkan perbedaan yang nyata akibat perlakuan $(\mathrm{p}<0.05)$.

\section{Kontribusi Zat Gizi Flakes Pati Garut}

Kandungan gizi flakes antara lain protein $16.90 \mathrm{~g}$, lemak $5.21 \mathrm{~g}$, karbohidrat $69.06 \mathrm{~g}$, energi $391 \mathrm{kkal} / 100 \mathrm{~g}$, kalsium $1448.50 \mathrm{mg} / 100 \mathrm{~g}$, dan fosfor $861.50 \mathrm{mg} / 100 \mathrm{~g}$. Untuk memenuhi target kaya protein, kalsium dan fosfor maka jumlah flakes pati garut yang dikonsumsi lansia adalah $72.00 \mathrm{~g}$. Dengan 
Tabel 4. Kandungan dan Kontribusi Zat Gizi Flakes Pati Garut per Takaran Saji (72.00 g) terhadap AKG Lansia

\begin{tabular}{lccccc}
\hline \multirow{2}{*}{$\begin{array}{c}\text { Kandungan } \\
\text { Gizi }\end{array}$} & \multirow{2}{*}{ Jumlah per Sajian $\mathbf{( 7 2 . 0 0} \mathbf{g})$} & \multicolumn{2}{c}{ AKG Lansia } & \multicolumn{2}{c}{ Kontribusi terhadap AKG (\%) } \\
\cline { 3 - 5 } & & Pria & Wanita & Pria & Wanita \\
\hline Energi (kkal) & 281.31 & 2050 & 1500 & 23 & 31 \\
Protein (g) & 12.17 & 60 & 50 & 20 & 24 \\
Kalsium (mg) & 1042.92 & 800 & 800 & 130 & 130 \\
Fosfor (mg) & 620.28 & 600 & 600 & 103 & 103 \\
\hline
\end{tabular}

kata lain, untuk memenuhi $20.00 \%$ AKG protein dan $15.00 \%$ AKG kalsium dan fosfor lansia harus mengonsumsi flakes pati garut sebanyak $72.00 \mathrm{~g}$. Kandungan zat gizi per takaran saji dan perhitungan AKG per sajian dapat dilihat pada Tabel 4.

Flakes pati garut dengan penambahan tepung lele dumbo memiliki kontribusi yang cukup terhadap pemenuhan AKG pada lansia, terutama energi dan protein. Berdasarkan Tabel 4 terlihat bahwa flakes pati garut telah mampu mencukupi kebutuhan untuk makanan sarapan pagi. Produk flakes pati garut ini dapat dikatakan sebagai makanan kaya energi, protein, mineral kalsium, dan fosfor. Hal ini dikarenakan kontribusi energi, protein, kalsium, dan fosfor per takaran saji flakes telah memenuhi lebih dari 20\% AKG energi dan protein lansia per hari dan lebih dari 15\% AKG mineral fosfor dan kalsium lansia per hari.

\section{KESIMPULAN}

Formulasi flakes pati garut dibuat dengan menambahkan tepung ikan lele dumbo (tepung kepala: badan ikan lele $=3: 7$ ) sebanyak 4 taraf yang terdiri dari $0.00 \%, 28.00 \%, 33.00 \%$, dan $38.00 \%$. Penambahan tepung ikan lele dumbo berpengaruh nyata terhadap atribut mutu warna, aroma, rasa, dan tekstur flakes pati garut $(\mathrm{p}<0.05)$. Formula terpilih adalah flakes pati garut dengan penambahan tepung ikan lele dumbo sebesar $33.00 \%$ (F2). Tingkat penerimaan flakes pati garut formula terpilih oleh lansia yaitu sebesar $88.71 \%$.

Tingkat kekerasan dan daya serap air flakes terpilih yaitu $190.45 \mathrm{gf}$ dan $5.59 \mathrm{ml}$. Kandungan gizi flakes terpilih yaitu kadar air 4.00\%, kadar abu $4.84 \%$, kadar protein $16.90 \%$, kadar karbohidrat $69.06 \%$, kadar kalsium $1448.50 \mathrm{mg} / 100 \mathrm{~g}$, dan fosfor $861.50 \mathrm{mg} / 100 \mathrm{~g}$. Flakes terpilih memiliki nilai daya cerna protein sebesar $75.00 \%$. Berdasarkan analisis kontribusi zat gizinya, flakes terpilih dapat memberikan kontribusi energi 23.23\% untuk pria dan $31.75 \%$ untuk wanita, protein $20.28 \%$ untuk pria dan 24.34 untuk wanita, kalsium $130.37 \%$ dan fosfor $103.38 \%$ pada kelompok lansia sehingga dapat diklaim sebagai produk kaya energi, protein, mineral, kalsium, dan fosfor.

\section{DAFTAR PUSTAKA}

Adriano G, Rafael S, Eduardo H, Walter, Amir M, Granato D, Jose A, \& Helena M. 2010. Sensory analysis: relevance for prebiotic, probiotic, and synbiotic product development. Food Science and Food Safety, 9(4), 358-373.

Chaunier L, Courcoux P, Valle G, \& Lourdin D. 2005. Physical and sensory evaluation of corn flakes crispness. Journal Texture Studies, 36(10), 93-118.

Chen J \& Stokes J. 2012. Rheology and tribology: two distinctive regimes of food texture sensation. Food Science and Technology, 25(1), 4-12.

Iriawan. 2012. Pembuatan fish flake dari ikan lele (Clarias sp.) sebagai makanan siap saji [skripsi]. Fakultas Perikanan dan Ilmu Kelautan, Institut Pertanian Bogor, Bogor.

Jyothi A, Sheriff J, \& Sajeev M. 2009. Physical and functional properties of arrowroot starch extrudates. Journal Food Science, 74(2), 97104.

Li P, Mai K, Trushenski J, \& Wu G. 2007. New developments in fish amino acid nutrition: towards functional and environmentally oriented aquafeeds. Journal Amino Acid, 37(1), 43-53.

Manton G, Lamb V, \& Gu X. 2007. Medicare cost effects of recent U.S. disability trends in the elderly future implications. Journal Aging Health, 19(3), 359-381.

Mervina, Kusharto CM, \& Marliyati SA. 2012. Formulasi biskuit dengan substitusi tepung ikan lele dumbo (Clarias gariepinus) dan isolat protein kedelai (Glycine max) sebagai makanan potensial untuk balita gizi kurang. Jurnal Teknologi dan Industri Pangan, 23(1), 9-16.

Oey I, Lille M, Loey A, \& Hendrickx M. 2008. Effect of high-pressure processing on colour, texture, and flavour of fruit-and vegetablebased food products: a review. Food Science and Techno-logy, 19(6), 320-326.

Rusilanti \& Kusharto CM. 2006. Model hubungan aspek psikososial dan aktifitas fisik dengan sta- 
Amalia \& Kusharto

tus gizi lansia. Jurnal Gizi dan Pangan, 1(1), 29-35.

Sayed M, Abdel A, Frank W, \& Mohamed M. 2003. Nutritional, functional and sensory properties of wheat, rice and fababean blends texturized by drum drying. International Journal of Food Science \& Technology, 31(3), 257-266. 